Article

\title{
Challenges and Prospects of Sustaining Donor-Funded Projects in Rural Cameroon
}

\author{
Gregory Nguh Muluh ${ }^{1}$, Jude Ndzifon Kimengsi ${ }^{2,3, * \mathbb{D}}$ and Ngwa Kester Azibo ${ }^{4}$ \\ 1 Grassfield Participatory and Decentralised Rural Development Project (GP-DERUDEP), North West Region, \\ P.O. Box 1116, Bamenda 5112, Cameroon; muluhgn@yahoo.com \\ 2 Department of Geography \& Environmental Studies, Catholic University of Cameroon (CATUC), Bamenda \\ P.O. Box 782, Bamenda 5112, Cameroon \\ 3 Faculty of Environmental Sciences, Technische Universitat Dresden, 01737 Tharandt, Germany \\ 4 Higher Institute of Agriculture and Rural Development, Bamenda University of Science and Technology, \\ P.O. Box 277, Bamenda 5112, Cameroon; kazibo@yahoo.co.uk \\ * Correspondence: jude_ndzifon.kimengsi@tu-dresden.de
}

Received: 11 October 2019; Accepted: 30 November 2019; Published: 7 December 2019

\begin{abstract}
For more than five decades, developing countries (including Cameroon) have been primary beneficiaries of donor-funded projects targeting many sectors, including agriculture and rural development. Cameroon's rural landscape witnessed a series of project interventions which emphasized sustainability. Although research efforts have been directed towards understanding the planning, implementation and impacts of donor-funded projects, not enough scientific information exists on the determinants, challenges and prospects of sustaining donor-funded projects in rural communities in Cameroon. For this study, the Investment Fund for Communal and Agricultural Micro-projects (FIMAC I) scheme, was used to diagnose the determinants, challenges and prospects for sustaining development projects in the North West Region (NWR) of Cameroon. A representative sample of 150 beneficiaries drawn from 20 farming groups in the NWR was conducted, to generate data which was complemented by interviews. The binary logistic regression results reveal the following: Although there is a significant change in the level of incomes for the FIMAC I project beneficiaries, its sustainability (mirrored through continuity) is dependent upon a myriad of socio-economic factors including family size, length of stay in the community, gender, education and the status of the beneficiary. Furthermore, the less transparent loan application process and the lack of collateral security were the main challenges faced by project beneficiaries. We argue that the introduction of soft loans with minimal demands for collateral security could increase beneficiary participation in projects, while beneficiary groups should further diversify their sources of capital and productive activities. The study does not only contribute to existing theoretical constructs on sustainable rural development, but also makes a succinct request for future studies to unbundle the conditions, under which donor-funded projects are rendered sustainable in rural contexts.
\end{abstract}

Keywords: donor-funded projects; challenges; project sustainability; determinants; FIMAC I; NWR

\section{Introduction}

At the dawn of independence, most African countries relied on technical, financial, material and institutional support from Western nations to chart their path towards development. The rising interest to support the rural development process of developing nations led to the streaming in of international development agencies (IDAs), and non-governmental organizations (NGOs) and several donor-funded project interventions. This trend witnessed a dramatic surge in the 1990s, as a rainbow of international donors championed rural development initiatives within the African landscape [1,2]. In spite of the 
varying visions and statements of intent, these donors generally converged on the need to alleviate poverty especially for the vulnerable, poor and rural masses. International donors channeled resources in some cases directly through local NGOs, but, in most cases, through government-specialized agencies by way of programs and projects. Donor funding therefore played an important role in this respect [3-5] as it was considered effective channels for development.

For more than five decades, developing countries have been the primary beneficiaries of donor-funded projects in a number of sectors including public health, agriculture, education, social and community development, and infrastructural development [5-7]. Despite the importance attached to donor-funded projects, a number of issues of concern have been raised in scientific and policy spheres. For instance, issues of project impact and sustainability have always been preoccupying [8-10] as there are significant constraints to the capacity of national governments to extend community development. To this effect, switching expenditure has become a protracted process in most of these countries. There have been numerous changes in the socio-economic climate of nations of the world, with massive increases in the rate at which national policies are adopting the system of sustainability. The concept of sustainable development seeks to strike a balance between the environment, society and the economy. It presupposes that developmental endeavors (projects in this case) should be accomplished in such a manner that the benefits are felt by future generations [11,12]. In addition to this, constraints on revenue-raising have emerged as a barrier to community development, especially in Sub-Saharan Africa. International development organizations have therefore emerged as important actors especially in short-term sectorial and infrastructure project lending, with emphasis on the application of sustainability issues in community development programs and projects $[9,10,13]$. It is against this background that this study was developed to diagnose the factors, challenges and prospects for sustaining donor-funded projects in rural communities in Cameroon, taking the case of the FIMAC I Loan Scheme. The Investment Fund for Communal and Agricultural Micro-projects (FIMAC) Scheme had a main objective to provide financial and technical assistance to self-help projects of low-income groups. Specifically, this scheme was meant to: enhance and ensure food self-sufficiency; improve on the technical and financial management capacity of farmers; ameliorate the purchasing power and hence the standard of living of the rural population; reduce the burden involved in farming by encouraging the use of improved farming tools; promote self-reliance development; consolidate grassroots organizations; educate and gradually introduce the rural population into the formal banking sector.

The technical assistance package of the FIMAC I Scheme was meant to ensure the sustainability of the activities financed by the financial package of the scheme. To that effect, beneficiary groups and front-line staff were trained on the technical aspects of the Scheme, including loans disbursement and recovery.

\section{Concise Review of Literature}

It is important to start this section by first defining some key concepts of interest to this study. In the development literature, development is viewed as a multi-dimensional concept [14]. It is not just about fulfilling poor people's basic needs, but also allowing them to choose how they develop and to choose which technologies they adopt [15-18]. Himmelstrand and Kinyanjui, for instance, defined development as the capacity to produce or provide the means of production to satisfy the consumption needs of the masses. This capacity has remained the domain of the state in the third world, positioning the poor as recipients [19]. Sustainability as a term connotes the magnitude of inheritance after donor support, the ability of the government to take over donor-supported programs, especially after evaluation and before the phasing out of the project, and the continuation of project activities upon the phasing out of donor support. In projects lexicon, sustainability is described as the capacity of projects to be "weaned". Development sustainability is therefore considered as the process of maintaining the production capacity and keeping the outcomes and impacts that ensue from project interventions [20]. The sustenance of rural development interventions, especially microfinance, is of interest to most rural development actors [21-23]. 
Microfinance is considered as a major credit disbursement mechanism in many parts of the world. The term can be used to denote micro credit, micro savings, micro insurance, transfer services and other financial products targeted to low-income people. It includes small savings, credit, and insurance services extended to socially and economically disadvantaged segments of the society. It is equally considered as the entire range of financial and non-financial services, including skill up-grading and entrepreneurship development, rendered to the poor for enabling them to overcome poverty [24,25]. The basic idea of micro credit is to loan to the rural poor small amounts of money so that they can start their own businesses. This makes it possible for poor people to be self-employed and self-sustaining by buying seeds, tools and equipment, or starting a small chicken farm, for example. Instead of giving support and/or grants, the idea is to use the skills and initiative of poor people to change the circumstances of their lives [26,27]. Similarly, beneficiaries who are already in business are able to use loans to expand their existing businesses, which could lead to improvement in living conditions [25]. The sustainability of micro credit interventions is of interest in this study.

\section{Sustainability of Development Projects}

The question of why projects fail has consistently preoccupied scholars and project practitioners over the years. Issues of sustainability in development interventions became very important to donors in the 1980s [28]. Sustainability became a very important criterion for project evaluation and represented the main purpose for donors providing aid in achieving or promoting development [29]. Sustainability implies the ability of a project to continue in operation to achieve its purpose for the longest time possible after the donor withdraws support $[4,30]$. In the context of this research, it represents the capacity of project beneficiaries to continue operating their farm activities/businesses and securing livelihoods after the financial support phase from donors has ended. A project is sustainable if it captured sustainability strategies from the design phase. However, sustainability could be influenced by how the project is managed, monitored and evaluated [31,32].

The UNESCO Science Report for 2016 reveals that many African countries have not waited for the adoption of the Sustainable Development Goals to embark on a more sustainable development path. Many of the long-term planning 'Vision' documents to 2020 or 2030 adopted by African countries over the past decade have identified sustainable development as being a pillar of their national development strategy, along with more inclusive growth and better governance. Regional economic communities are also conscious that developing an African Economic Community by 2028 will need to go hand in hand with greater scientific integration and more sustainable development. For instance, the Vision 2020 document adopted by the Economic Community of West African States (ECOWAS) in 2011 aspires to "create a borderless, prosperous and cohesive region built on good governance, where people have the capacity to access and harness its enormous resources through the creation of opportunities for sustainable development" [32].

A report by [33] revealed that there is a difference between Africa and Asia in their transition from extensive to intensive agriculture. As shown by data on cereal yield and fertilizer consumption per hectare, South East Asian countries have made greater progress than sub-Saharan countries in modernizing their agricultural sector, thereby substantially increasing productivity per hectare. This has led to a higher GDP in Asian than African countries. According to them, African countries must be granted the policy space to adopt industrialization policies that are adapted to the reality of the 21st century globalized economy [34], including effective measures to temporarily protect its infant industry.

On the other hand, income inequality tends to be higher in some sub-Saharan African countries than in South East Asia. While the high level of income concentration in many sub-Saharan countries may appear as counterintuitive according to [35], being relatively poor and with a large share of the population concentrated in agriculture, Africa should be characterized by a relatively lower degree of social inequality than richer, more industrialized countries. Since sustainability seeks to actively involve the people in the environment in order to attain sustainable development, the existence 
of poverty and environmental degradation pushes sustainability to fail. This is probably because sustainable development works with all the tools and human capital that can be found within a given project environment. This explains why development projects in Africa are mostly less sustainable than development projects in Asia for instance [33].

The environment is of strategic importance to Africa's sustainable development drive. The Environmental Initiative of the New Partnership for Africa's Development (NEPAD) has acknowledged that a productive and healthy environment is necessary in that it is critical to the creation of the ecological and social base as a veritable platform for the partnership to thrive. Before the inception of NEPAD, African leaders had acknowledged that the environment and its resources are relevant to the continent's development and therefore put measures in place for its conservation and protection [36,37]. There is strong evidence that environmental degradation and devastation can destroy people's livelihoods and inflict insecurity in a nation. For example, some developing economies such as Nigeria that have not been able to manage their oil and gas resources very well have had to deal with oil spillage over the years with attendant destruction of the ecosystem of communities where oil exploration took place. Oil spillage does not only destroy the fertility of the land but also destroys aquatic lives upon which the people depend for their sustenance [37]. Other studies have shown that Africa and Asia contribute large amounts of waste that reaches the oceans. For instance, it has been revealed that just 10 rivers across Africa and Asia carry $90 \%$ of the total plastic waste that end up in our oceans [37]. This is probably why [36] recommended a comprehensive approach to handling the challenge of environmental devastation as part of efforts to actualize the right to environment and attain sustainable development in Africa. These and more have led to emphases on holistic approaches for the socio-economic emancipation of rural populations by donor organizations.

This has been accompanied by the definition of new priorities, partners, platforms and financing modalities-all of which have important repercussions for the organization and execution of agricultural development in Africa [36,38].

The proposed theoretical framework for this study is guided by interlinked concepts of agriculture and rural development, microfinance, institutions and project sustainability. The framework therefore seeks to integrate these essential elements, drawing from diverse lines of thought on them. The theoretical framework is presented in Figure 1.

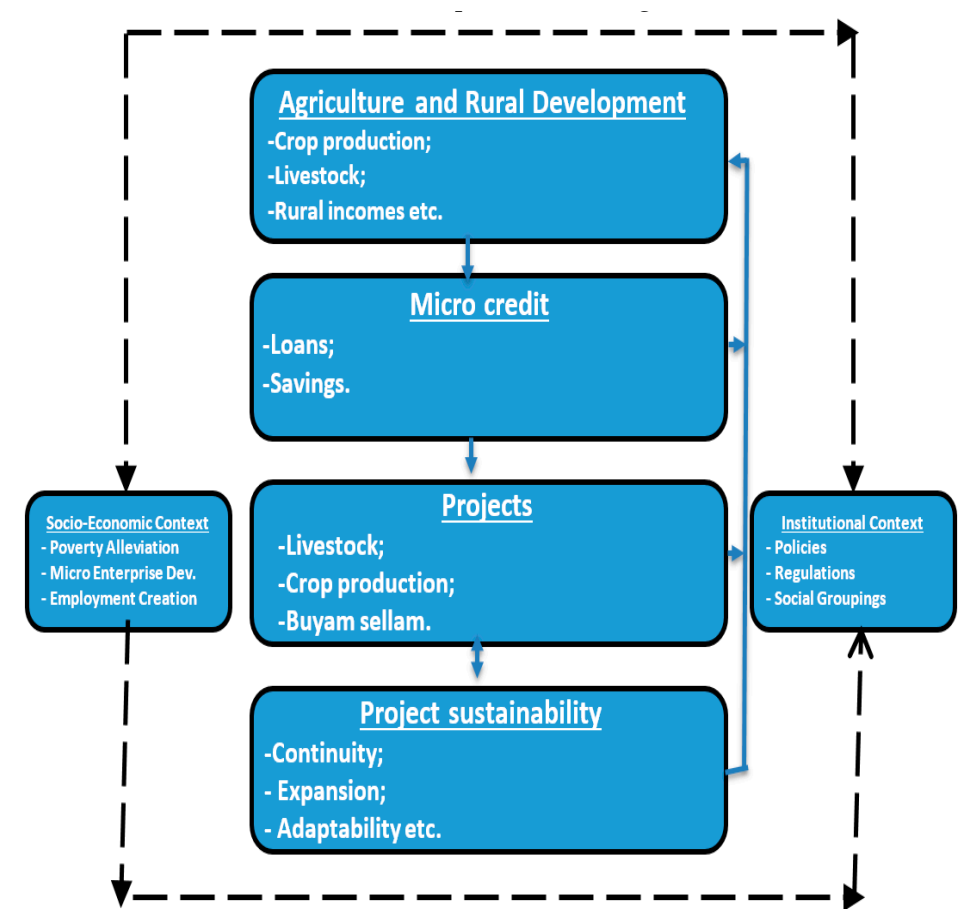

Figure 1. Framework on rural development and project sustainability. Based on: [30-32,39,40]. 
The framework explains that agriculture and rural development interventions are realized through micro credit initiatives (savings and loans) leading to the implementation of crop farming, livestock and micro-enterprise projects by beneficiaries. Beneficiaries are expected to continue operating after initial support (sustainability) while feedback is provided in the design of future donor-funded projects which operate within defined socio-economic and institutional contexts.

The situation described gives this study its significance as it has focused on analyzing the challenges inherent in the sustenance of donor-funded projects, taking the case of a project in Cameroon. In Cameroon, a number of donor-funded projects have been introduced to support rural development. Classical examples in the North West Region include the Upper Nun Valley Development Authority (UNVDA), Agricultural Competitiveness Project (PACA), Grassfield Participatory and Decentralized Rural Development Project (GP-DERUDEP), the Program for Improvement of Competitiveness of Family Agro Pastoral Farms (ACEFA) and the Investment Fund for Communal and Agricultural Micro-projects (FIMAC). FIMAC, which came into enforcement in 1990, was extended to all 10 regions of Cameroon by 1991 with focus on financing agricultural and rural development projects.

Research efforts have been directed towards aspects of project planning and implementation. In addition, scholars in the field of rural development and project management have equally evaluated the impact of donor support projects and the reasons for project failures [40-42]. This has been followed by a further assessment of the sustainability strategies of donor-funded projects with a view to improving them. In the North West Region, the socio-economic impacts of donor-funded projects especially in the agricultural sector have been investigated [43-46]. Furthermore, the role of capacity building and resource mobilization on project sustainability has equally been investigated [47-50]. Recently, the links between project planning and sustainability for agricultural development projects in the North West was equally established [51]. However, some issues, which seem to have eluded scientific studies in project management and rural development in the North West Region, include amongst others the determinants, challenges, current efforts and future prospects of sustaining donor-funded projects. This study seeks to address the current lacunae by analyzing the determinants, challenges, attempted efforts and future prospects for sustaining the FIMAC project in the North West Region of Cameroon. The results of this study will certainly help the projects that are currently being executed in the region and those that would be executed in the future.

\section{Materials and Methods}

\subsection{Study Area}

The North West Region (Figure 2) is one of the ten regions of the Republic of Cameroon. It lies between latitudes $5^{\prime} 43^{\prime \prime}$ and $7^{\prime} 9^{\prime \prime} \mathrm{N}$ and longitudes $9^{\prime} 13^{\prime \prime}$ and $11^{\prime} 13^{\prime \prime} \mathrm{E}$. It is bordered to the north and west by the Federal Republic of Nigeria, to the south by the South West Region, to the southeast by the Western Region, and to the east by the Adamawa Region. 


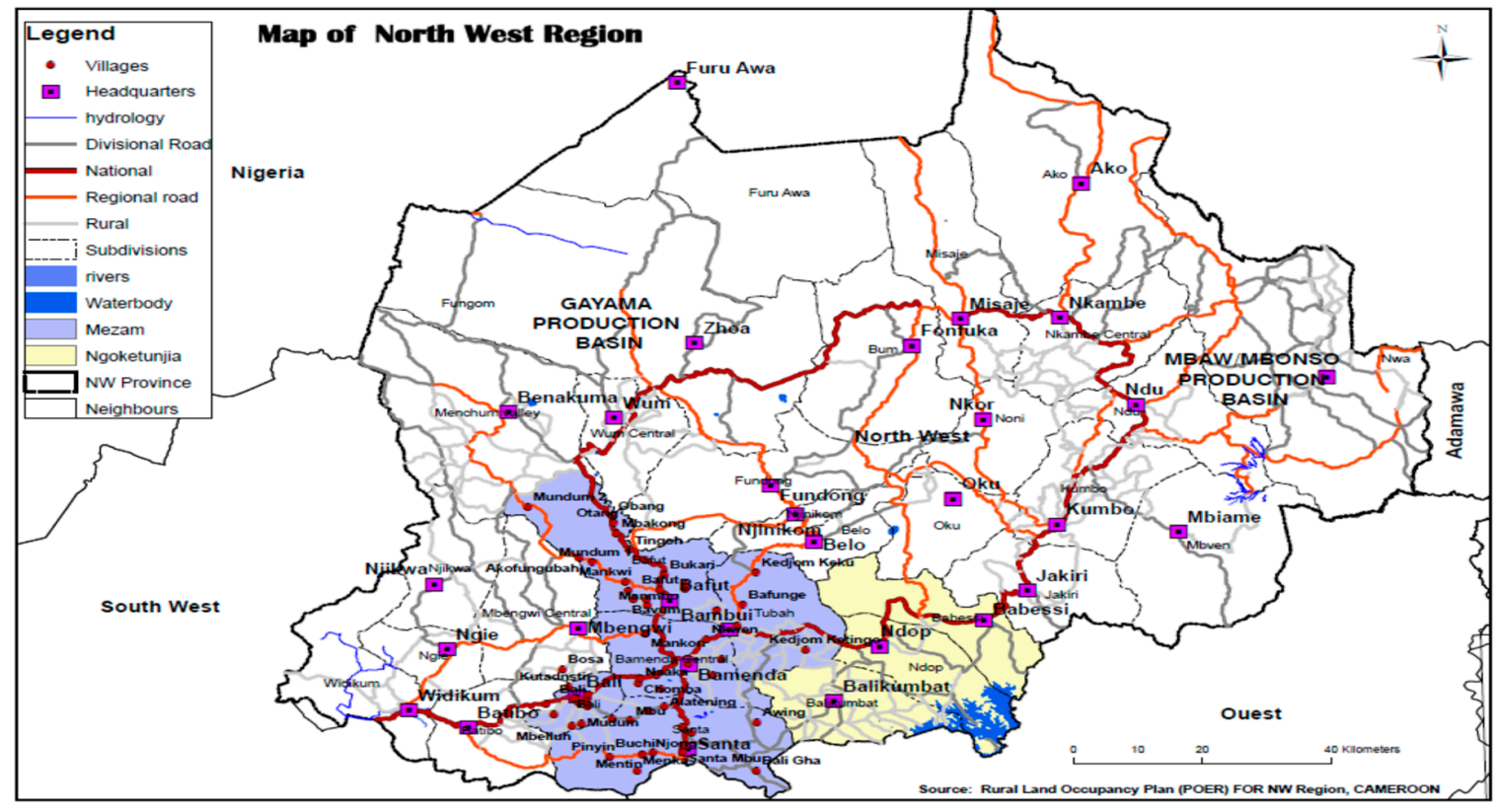

Figure 2. Map of study area: Source: [52].

The region has an area of about $17,910 \mathrm{~km}^{2}$ with an estimated population of approximately 1.85 million. Its population density of 99.12 people per square kilometer is higher than the national average of 22.6. The regional urban growth rate is $7.95 \%$ higher than the national average of $5.6 \%$, while the rural growth rate, at $1.16 \%$, is equal to the national rate. Administratively, the region is divided into seven (7) divisions and thirty-four (34) sub-divisions and 43 municipal councils [53]. The topography of the region is generally mountainous and undulating, characterized by abrupt escarpments, towering mountain peaks, deep valleys and broad alluvial plains. The highest point in the region is Mount Oku (in the Bui division) with an altitude of $3011 \mathrm{~m}$ and the lowest being Mbembe plain with an altitude of $211 \mathrm{~m}$ above sea level. The rough terrain explains the difficulties encountered in the attempts to reach a greater part of the region either by vehicle or even on foot. Some areas are still enclave and not accessible by road. This study was conducted in two divisions of the region (Mezam and Ngoketunjia). These two divisions represent $26.3 \%$ of the total number of farmers involved in the FIMAC I loan scheme. More so, all the speculations financed by the scheme in the North West Region were found in these two divisions. The target population consists of 1100 beneficiaries of the FIMAC Phase I Loan Scheme in the study area [53,54]. Of this number, 150 beneficiaries $(13.6 \%)$ were randomly sampled. Taking into consideration that a $10 \%$ sample is representative for this kind of study, a sample of 150 beneficiaries, representing $13.6 \%$ of the target population, was considered good enough to provide the relevant data for the study [55].

\subsection{Sampling Design}

The design for this investigation was based on a mixed-methods approach. The case unit selected was the Mezam-Ngoketunjia Axis of the Region, which was considered a fair representation of the FIMAC I Loan beneficiaries of the North West Region. The study employed both exploratory and descriptive research approaches. Exploratory tools were used to analyze the determinants for the sustenance of FIMAC I projects in the region as well as to evaluate the challenges faced in sustaining the scheme. Descriptive tools were used to assess the efforts being made to address the challenges and the prospects for sustaining the scheme in the region. The evaluation combines both quantitative and qualitative methods. Quantitative data on the one hand was collected on aspects such as income, farm sizes, yields, savings, etc. On the other hand, qualitative data was collected on issues regarding project sustainability, challenges and future prospects. Because of the absence of baseline information, 
the questionnaire for project contribution was designed for a 'before' and 'after' comparison. See, for instance, the cases of $[43,46,56]$.

\subsection{Data Collection}

The data collected for this work came from two sources, primary and secondary sources. The primary data were collected using a structured questionnaire (Appendix A), while institutional reports were consulted for secondary data.

\section{Primary Sources}

The technique that was used in selecting the beneficiaries to administer the questionnaires and the interviews, was the simple random sampling technique. After getting the list of all the beneficiaries of the scheme in the Mezam and Ngoketunjia divisions, the researchers randomly selected the communities that were visited. The names of the various communities were written on pieces of papers and dropped into a box. From this lot, the communities were then randomly selected one after the other without repetition until the list of communities was full. The same technique applied to those who were interviewed, though we had a very limited sample from which to select the staff to interview, as most of the staff who participated in the management of the scheme were either transferred out of the area or were already on retirement and not reachable. The random sampling technique was used because of the homogenous nature of the beneficiary population in the two divisions and also due to the fact that most of the communities had all the sectors financed by the scheme.

In the first step, key informant interviews were conducted with those who were involved in the management of the FIMAC I scheme and the staff of Financial Institutions. Details on the kind of activities that were financed and their regularity, the number of loan files treated annually, the impact of the scheme at various levels, the challenges encountered in the management of the scheme, the proposed way forward to the challenges encountered, the sustainability of the scheme etc., were collected for analysis. From the discussions, variables were identified and captured in the survey instrument (structured questionnaire) used to interview the beneficiaries.

In the second step, the survey instrument developed was submitted to peers for review who gave inputs and directives for its revision. A pilot test of the tools was conducted involving 12 randomly selected beneficiaries in the study area by 4 trained surveyors. The feedback from the pilot test was used to further revise the questionnaire. Presented in Table 1 below is the distribution of the respondents in the different communities in the two divisions in which this study was conducted.

Table 1. Distribution of questionnaires in the study area.

\begin{tabular}{cccc}
\hline Community & Section & No. Administered & No. Retrieved \\
\hline Bafut & Mezam & 8 & 8 \\
\hline Bali & Mezam & 5 & 5 \\
\hline Nkwen & Mezam & 16 & 16 \\
\hline Santa & Mezam & 33 & 33 \\
\hline Tubah & Mezam & 40 & 40 \\
\hline Babessi & Ngohketunjia & 12 & 12 \\
\hline Ndop & Ngohketunjia & 36 & 36 \\
\hline Total & & 150 & 150 \\
\hline
\end{tabular}

The team members otherwise referred to in the questionnaire as surveyors through the assistance of the Sub-Divisional Delegates of Agriculture and Rural Development in the two selected divisions identified 150 beneficiaries to be administered the questions. Appointments were taken with each member depending on their availability. The surveyors met the members, explained in details the 
objective of the study and assured them of the confidentiality of the information and their identities. Each session with the respondents was preceded by this assurance. The questions were then asked systematically and answers recorded on the questionnaire. Some of the respondents had no answers to some questions while some, especially the elderly, said they could not remember the answers. Mostly the women and children referred the surveyors to their husbands and fathers respectively, claiming that they just signed the documents but never had anything to do with the finances/equipment given. The data collection exercise was conducted between March and May, 2018.

\subsection{Ethical Considerations}

The Regional Delegate of Agriculture and Rural Development for the North West Region was contacted for clearance, since the Scheme is under the Ministry of Agriculture and Rural Development. The authorization was then communicated to the divisional and sub-divisional Delegates of Agriculture and Rural Development for Mezam and Ngoketunjia, who gave maximum support to the surveyors who assisted in administering the questionnaire and interviews. Authorities and organizations solicited to provide necessary information for this study were very collaborative. Consent from respondents was orally obtained to let them know the reasons for the study and they were assured of the confidentiality of all information that they would provide, as well as their identities. This assurance made all those who were contacted for both the questionnaires and interviews to provide the information without fear of being exposed.

\subsection{Data Analysis}

The collected data were analyzed using SPSS for Windows (Statistical Package for Social Sciences) software version 25.0 and Microsoft Excel 2010. At a 95\% confidence interval $(\alpha=0.05)$, both descriptive and inferential statistics were performed. Frequency distributions (presented in the form of charts and tables) were used to describe the socio-economic situation of the sample population, the impacts of the FIMAC I loan scheme, the challenges of sustaining the FIMAC I loan scheme, efforts being made so far to address the challenges of sustaining the FIMAC I loan scheme, as well as the prospects for sustaining the FIMAC I loan scheme. Binary logistic regression was employed to ascertain the determinants for the sustenance of FIMAC projects as well as the hypothesis that "the likelihood of continuity of the FIMAC loan scheme is a function of the socio-economic characteristics of the beneficiaries".

In order to analyze the factors affecting project sustainability, the weakness of the linear probability model do not allow for the usage of the Ordinary Least Squares (OLS) technique. The logit or probit model is more convenient because the dependent variable (project sustainability) is qualitative in nature, the explanatory variables are a mix of continuous and qualitative variables and the sample size $(n=150)$ is low [57]. The choice between the logit and probit models is more or less based on convenience and ease of interpretation. Based on these, binary logistic regression was adopted for this analysis.

The dependent variable (project sustainability) took 1 for sustainable and 0 otherwise. By denoting $P$ as the probability of reaching an alternative from the predictors $X_{1}, X_{1} \ldots \ldots X_{n}$, the mathematical formula for the binary logit model [43,57-59] used in this study is expressed in Equation (1):

$$
\operatorname{Logit}(P)=\ln \left(\frac{P}{1-P}\right)=\propto+\beta 1 \times 1, \beta 2 X 1 \ldots \ldots . \operatorname{BnXn}
$$

where:

$P$ : Probability that the project is sustainable

$1-P$ : Probability that the project is not sustainable

$\mathrm{X}_{1}, \mathrm{X}_{1} \ldots \ldots \ldots \mathrm{X}_{\mathrm{n}}$ : Different predictor/explanatory variables 
In the logit model Equation (1), the notations $\beta_{1}, \beta_{2}$ and $\beta_{n}$ (generally termed as $\beta$ ) denote the slope coefficients of the explanatory variables $X_{1}, X_{1} \ldots \ldots \ldots X_{n}$ (generally termed as $X$ ) and $\alpha$ is the intercept term (constant).

In this study, sustainability was captured using three arms which are:

Adaptability where by a project is considered sustainable if the beneficiary is readily able to anticipate and adapt to change through clear decision-making as a result of the project.

Continuity whereby the beneficiary can continue the project upon its completion and without external financial assistance

Extension where by the beneficiary can extend project activities at household and community levels upon its completion and without external financial assistance $[31,60,61]$

In our model (s), the dependent variable (s) therefore took 1 if the project is adaptable, has been continued or can be extended and 0 otherwise. The process of information flow can be graphically represented as has been summarized in Figure 3 below:

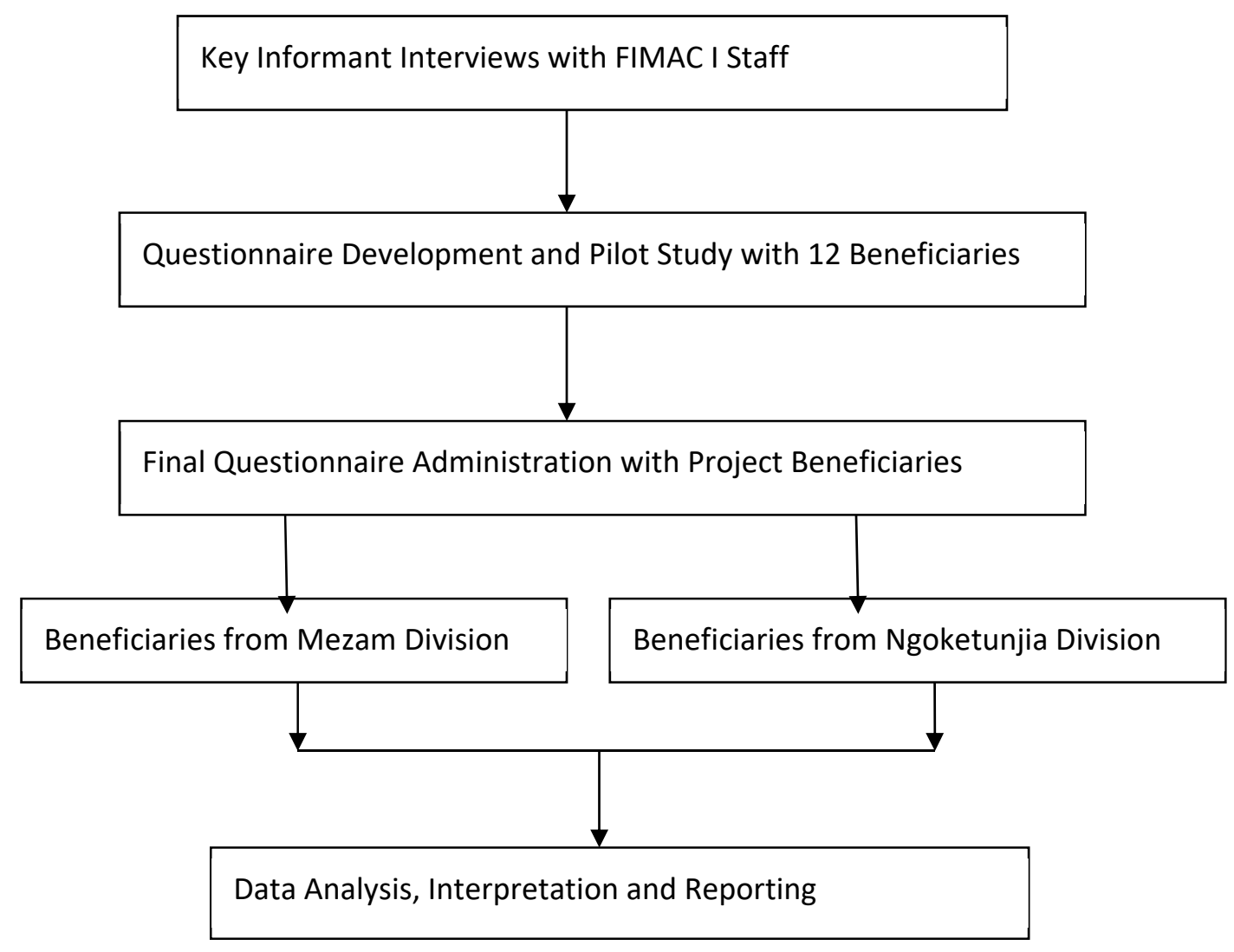

Figure 3. Graphical representation of information flow.

\section{Results}

\subsection{Socio-Economic Description of Sample Population}

Before discussing the characteristics of the beneficiaries, it is worth introducing some aspects of the FIMAC I project. The FIMAC I project had three dimensions which were: training, provision of equipment and provision of financial capital (loan). Being the interest of this paper (loan scheme), our findings revealed that through the FIMAC I loan scheme, some beneficiaries were given as high as FCFA 4,500,000 while others received only FCFA 16,000. From Table 2 below, one can clearly identify the main areas of investments within the project which are the agricultural sector (37.7\%), the livestock sector $(31.5 \%)$ and businesses $(30.8 \%)$. More so, while most of the beneficiaries $(87.3 \%)$ received their 
loans on an annual basis, a small proportion of about 3\% mentioned they did not receive any loan from the FIMAC scheme, but their names were on the list of the beneficiaries. Some respondents indicated that they were not even aware of the FIMAC I loan scheme at the time of the implementation of the project while others mentioned that the loan was only available at the level of the cooperative, as individuals were not given loans.

Table 2. Investment sector and frequency of FIMAC I support.

\begin{tabular}{cccccc}
\hline Variable & \multicolumn{2}{c}{ Crop Production (Agriculture) } & \multicolumn{2}{c}{ Livestock Production } & Other Business \\
\hline $\begin{array}{c}\text { Sector of } \\
\text { investment }\end{array}$ & \multicolumn{2}{c}{$37.7 \%$} & \multicolumn{2}{c}{$31.5 \%$} & $30.8 \%$ \\
\hline \multirow{2}{*}{$\begin{array}{c}\text { Support } \\
\text { frequency }\end{array}$} & Monthly & Once & Yearly & Bi-annually & Never \\
\cline { 2 - 7 } & $0.7 \%$ & $5.3 \%$ & $87.3 \%$ & $4 \%$ & $2.7 \%$ \\
\hline $\begin{array}{c}\text { Amount } \\
\text { received }\end{array}$ & Age & Seasonal income & Occupation & Education & Sex \\
\hline
\end{tabular}

Note: $\mathrm{r}=$ Spearman's correlation coefficient, ${ }^{* *}=$ Significant at $5 \%$ and ${ }^{* * *}=$ Significant at $1 \%$.

Due to the disparity in financial support received, a correlation analysis was conducted between the amount of loan received and the age, sex, seasonal income, education, main occupation and the sector of investment of the FIMAC I loan. As can be inferred still from Table 2, the results indicate positive relationships with the age of the respondent $\left(\mathrm{r}_{(150)}=0.044, p>0.05\right)$, the estimated seasonal income $\left(\mathrm{r}_{(150)}=0.243, p=0.018\right)$, the main occupation of the respondent $\left(\mathrm{r}_{(150)}=0.137, p>0.05\right)$ and the sector of investment $\left(\mathrm{r}_{(150)}=0.288, p>0.003\right)$ and not with education and sex. This indicates that older individuals whose main occupation is agriculture and with higher seasonal income irrespective of their educational level and gender, received higher financial support from the FIMAC I project.

The distribution as can be inferred from Table 3 indicates that while some beneficiaries had no children to care for, some had as many as 13 dependents and 18 adult children to care for. In addition, some households had as small as FCFA 15,000 while others had as much as FCFA 2,500,000 as income in a single farming season. More so, some of the beneficiaries were found to have lived only for 10 years in their community while others had lived their whole life (over 89 years) within their respective communities. The length of stay in the community for instance may be looked upon as an additional advantage towards the acquisition of the FIMAC I loan as well as its sustainability.

Table 3. Descriptive analysis of the socio-demographic situation of respondents.

\begin{tabular}{ccccc}
\hline Variable & Minimum & Maximum & Mean & Std. Deviation \\
\hline Number of dependent children & 0 & 13 & 3 & 3 \\
Number of adult children & 0 & 18 & 5 & 4 \\
Estimated income/FCFA & 15,000 & $2,500,000$ & 736,600 & 582,500 \\
Length of stay in the village/years & 10 & 89 & 56.58 & 17.334 \\
\hline
\end{tabular}

Note: 1 . Number of children has been rounded to the nearest whole number, 2 . Income has been rounded to the nearest 10th franc.

An analysis and distribution of the beneficiaries according to livelihood sources show that farming was the main source of household livelihoods as reported by $72 \%$ of the respondents (see Figure 4). This was closely followed by those whose main livelihood source was business (about $17 \%$ ). However, some were in the civil service (about $7 \%$ ) while the rest had other professions such as nursing, teaching, etc. 


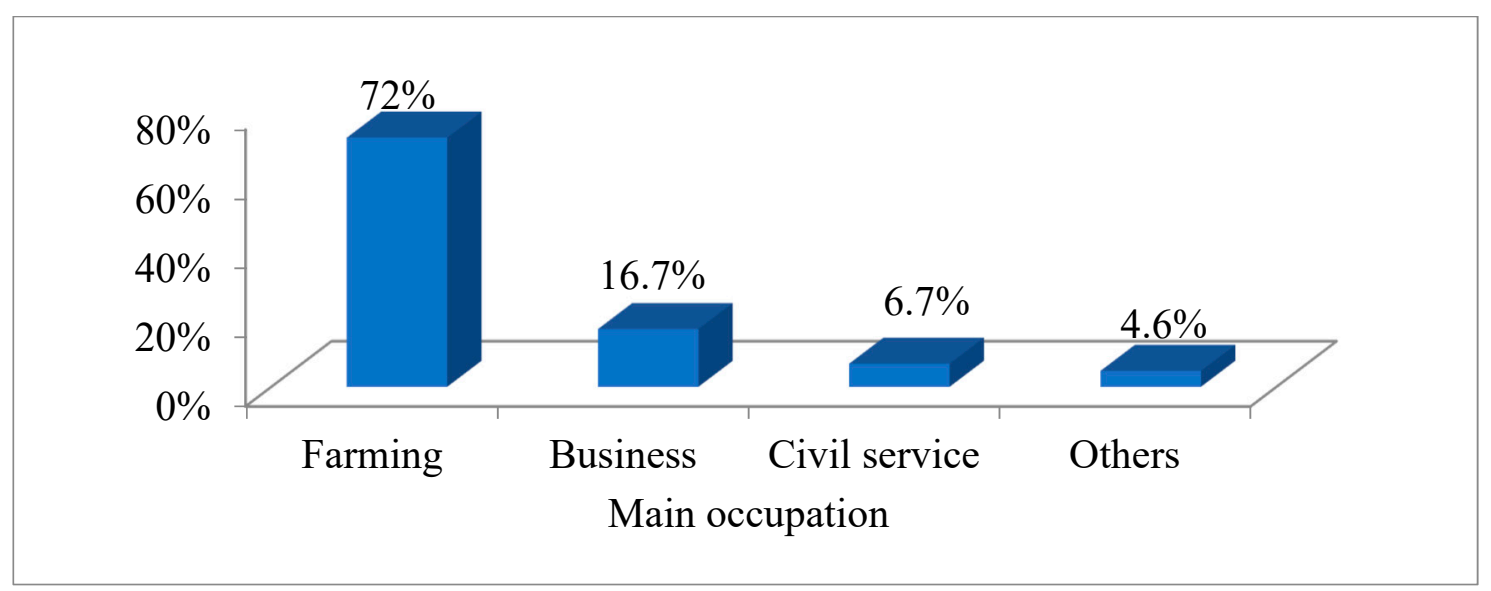

Figure 4. Main occupation of beneficiaries.

It is also worth mentioning that in this study, the majority of the respondents interviewed were males $(52 \%)$ as compared to females (48\%). Further, the age distribution of the respondents showed that while some of them were as old as 89 years, some were as young as 31 years. However, the mean age of the surveyed groups was slightly above 64 years $(64.33 \pm 10.32)$. Also, the majority of the beneficiaries had only a primary level of education (41.5\%). Second to this were those who had no formal education and were illiterate, i.e. who could not even read and write (close to $27 \%$ ). The third category belonged to those with a secondary school level of education (over 20\%). However, while close to $9 \%$ had been given vocational training, a very small proportion of about $3 \%$ had a university level of education (Bachelor's degree). Lastly, while $78 \%$ of the beneficiaries were indigenes of their respective communities, $22 \%$ represented those who migrated and settled in the community.

\subsection{Impact of FIMAC I Loan Scheme}

Table 4 below presents the impacts of the FIMAC loan scheme on the beneficiaries ranging from land holdings, production (yields) to income and savings.

Table 4. Impact of FIMAC Loan Scheme.

\begin{tabular}{ccccc}
\hline Test Variable & Situation & Maximum & Mean & Std. Deviation \\
\hline \multirow{2}{*}{ Total land holding/ha } & Before FIMAC Scheme & 16 & 2.36 & 3.06 \\
& After FIMAC Scheme & 60 & 4.24 & 6.78 \\
\hline Quantity of crop & Before FIMAC Scheme & 162 & 10.6 & 20.8 \\
produced/tons & After FIMAC Scheme & 523 & 31.1 & 66.8 \\
\hline Number of & Before FIMAC Scheme & 300 & 8 & 30 \\
livestock owned & After FIMAC Scheme & 300 & 14 & 40 \\
\hline Agricultural income per & Before FIMAC Scheme & 1684.2 & 213.1 & 287.7 \\
season/USD & After FIMAC Scheme & 2021 & 401 & 499.3 \\
\hline Estimated livestock & Before FIMAC Scheme & 1263.1 & 96.4 & 211.4 \\
income/USD & After FIMAC Scheme & 3536.7 & 249.1 & 440.6 \\
\hline Income from other & Before FIMAC Scheme & 2021 & 163.2 & 344.8 \\
sources/USD & After FIMAC Scheme & 3031.5 & 260 & 541.2 \\
\hline \multirow{2}{*}{ Monthly savings/USD } & Before FIMAC Scheme & 252.6 & 19.9 & 32.3 \\
\hline
\end{tabular}

$(\mathrm{n}=150), 1$ USD (United States Dollars) = FCFA 593.77 as of 26th September 2019; Source: [62]. 
As can be inferred from Table 4, the average total land owned by the beneficiaries increased from 2.36 hectares to 4.24 hectares following the implementation of the FIMAC loan scheme. Due to the benefits of increased agricultural land, for instance through increased farm outputs, similar results were obtained with respect to the average quantity of crops produced. The results revealed that the average quantity of crops produced increased from 10.6 tons to 31.1 tons following the implementation of the FIMAC I loan scheme. While agricultural production through increased land and crop cultivation increased, there was also a corresponding increase in livestock from an average of 8 to 14 following the implementation of the FIMAC I loan scheme. Some farmers who had no poultry before were given 300 birds to fatten and sell. With this increase in crop and animal production, income levels were bound to witness an increase. Mean agricultural and livestock incomes following the implementation of the FIMAC I loan scheme increased from USD213.1 to USD401 (a difference of USD187.9, an 88.1\% increase) and from USD96.4 to USD249.1 (a difference of USD152.7, an 158\% increase), respectively.

As a secondary impact, there were investments made by the beneficiaries in other sectors, for instance their private businesses or the purchase of equipment, which they use in their individual skilled jobs. It was observed that mean income from these sectors increased from USD163.2 to USD260 (a difference of USD96.8, 59.2\% increase). These translated into an increase in the mean monthly savings by $122.1 \%$.

\subsection{Determinants for the Sustenance of FIMAC Projects}

For this analysis, a binary logistic regression test statistic was employed to explain our model (see Section 3.5 for justification of choice of model). In the analysis, the dependent variable (project sustainability) took 1 for YES and 0 for NO. A total of 19 explanatory socio-economic variables were included in the analysis, which are age, number of adult children, number of dependent children, length of stay in the village, sex, main occupation, educational level, status (indigene or migrant), investment sector, institutions respondents have access to, networks to which the beneficiary holds membership, the type of cooperative benefits, land owned, income from other sources, loan training, livestock kept, received training in last five years, crops produced and the amount of loan received by the beneficiary. The analysis was done using the three dimensions of sustainability captured in this study (adaptability, continuity and extension) and the results combined to see which variables are robust in affecting project sustainability. The results are presented from Tables 5-7 below.

Table 5. Omnibus tests of model coefficients.

\begin{tabular}{cccc}
\hline Step & Chi-Square & Df & Sig. \\
\hline Adaptability & 62.271 & 18 & 0.000 \\
\hline Continuity & 71.458 & 18 & 0.000 \\
\hline Extension & 54.599 & 18 & 0.000 \\
\hline
\end{tabular}

Table 6. Regression model summary.

\begin{tabular}{cccc}
\hline Step & $\mathbf{- 2}$ Log Likelihood & Cox \& Snell R Square & Nagelkerke R Square \\
\hline Adaptability & 53.107 & 0.470 & 0.680 \\
Continuity & 49.270 & 0.518 & 0.731 \\
Extension & 49.777 & 0.427 & 0.652 \\
\hline
\end{tabular}


Table 7. Determinants for the sustenance of FIMAC beneficiary projects.

\begin{tabular}{cccc}
\hline & Adaptability & Continuity & Extension \\
\hline Age of beneficiary & 0.047 & -0.030 & $-0.144^{*}$ \\
Number of adult children & 0.152 & -0.115 & $-0.377^{*}$ \\
Number of dependent children & $0.550^{*}$ & 0.202 & 0.174 \\
Length of stay in the village & 0.010 & 0.009 & 0.047 \\
Sex of beneficiary & -0.082 & -0.668 & 0.709 \\
Main occupation of beneficiary & 0.426 & $-2.291^{* *}$ & $-1.196^{*}$ \\
Educational level & 0.358 & $2.007^{* *}$ & $0.967^{*}$ \\
Status (indigene or migrant) & $-1.887^{*}$ & $-3.391^{* *}$ & 0.957 \\
Sector of investment & 0.121 & 0.288 & $0.751^{*}$ \\
Institution with access & -0.195 & 0.017 & -0.164 \\
Networks of membership & $0.533^{*}$ & -0.795 & -0.244 \\
Cooperative benefit & $0.824^{*}$ & 0.212 & $-0.782^{*}$ \\
Total land owned & $0.368^{*}$ & -0.062 & 0.550 \\
Income from other sources & $0.000^{* *}$ & 0.000 & $0.000^{* *}$ \\
Received loan training & 1.832 & -0.108 & -0.303 \\
Livestock kept & 90.873 & -0.061 & 0.005 \\
Received training in last 5 years & -0.186 & 0.745 & -0.649 \\
Crops produce & $-0.034^{*}$ & $0.066^{*}$ & $0.166^{*}$ \\
Amount received & 0.000 & 0.000 & 0.000 \\
Constant & $-7.275^{*}$ & 7.176 & 5.933 \\
\hline
\end{tabular}

Note: ${ }^{*}=$ Significant at $10 \%,{ }^{* *}=$ Significant at $5 \%$.

As presented in Table 5, the attributes of our models indicate that there is a significant positive relationship between the dependent variables (adaptability, continuity and extension, all representing project sustainability) and the independent variables (Chi-square (adaptability) $=62.271, p=0.000$, Chi-square $_{(\text {continuity) }}=71.458, p=0.000$ and Chi-square ${ }_{(\text {extension) }}=54.599, p=0.000$ )

In addition, the attributes of Table 6 reveal that following Nagelkerke R Square, the model explains $68 \%$ of the factors that affect project adaptability, $73.1 \%$ for project continuity and $65.2 \%$ the extension of the FIMAC I beneficiary projects. Put together, they explain $67.9 \%$ of the factors that affect the sustainability of the FIMAC sponsored projects in rural Cameroon.

As can be inferred from Table 7 below, 12 of the 19 variables tested affected the adaptability of the beneficiaries to the FIMAC I projects. In the same light, 8 of the 19 variables affected the continuity of the FIMAC I sponsored projects while 9 of the 19 variables affected the extension of the FIMAC beneficiary projects in the North West Region.

The regression results as presented in Table 7 below indicate that the number of dependent children $(B=0.550$ for adaptability, $B=0.202$ for continuity and $B=0.174$ for extension), the length of stay in the village ( $B=0.010$ for adaptability, $B=0.009$ for continuity and $B=0.047$ for extension), the educational level of the beneficiary $(B=0.358$ for adaptability, $B=0.2007$ for continuity and $B=0.967$ for extension) and the sector of investment $(B=0.121$ for adaptability, $B=0.288$ for continuity and $\mathrm{B}=0.751$ for extension) were robust across all three dimensions and showed positive relationships in affecting the sustainability of the FIMAC sponsored projects in the North West Region of Cameroon. Mixed results were obtained with respect to the age of the beneficiary, the sex of the beneficiary, his/her status as to whether they are an indigene or a migrant in the villages, the total land owned, training received, number of adult children, main occupation, access and membership in groups, benefits from groups, total livestock kept and the quantity of crops produced. It is worth mentioning that income from other sources and the amount of loan received did not lend themselves as crucial variables in controlling the sustainability of the FIMAC project in the North West region of Cameroon $(B=0.000$ for all three dimensions).

The results presented in Table 7 are mixed. For instance, while the age of the beneficiary, the number of adult children, the main occupation, total land owed, received training, livestock owned, belonging to groups or networks and the type of benefits obtained from these groups were positive in 
affecting adaptability, project continuity was rather positively affected by access to institutions and benefits received, received training in the last five years and the quantity of crops produced by the beneficiary. Mixed results were also recorded with project extension as it was positively affected by the sex of the beneficiary, the status, the total land owned, livestock kept as well as the quantity of crops cultivated.

\subsection{Challenges Faced in Acquring the FIMAC I Loan}

Figure 5 presents the challenges faced during the implementation of the FIMAC I loan scheme.

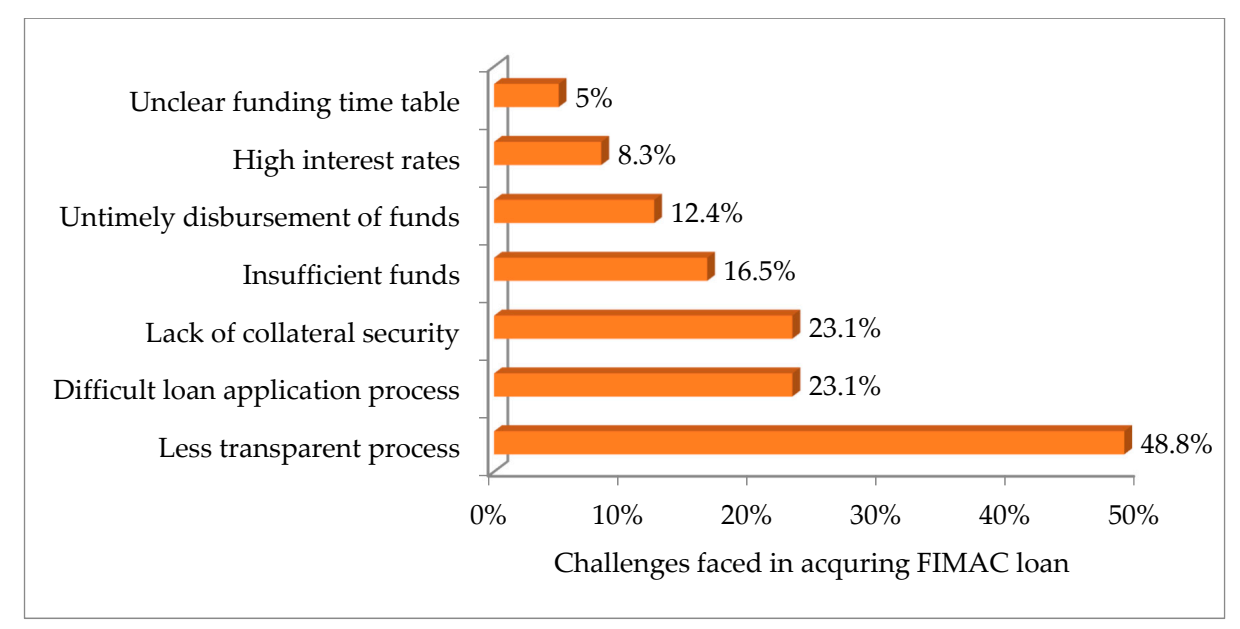

Figure 5. Challenges faced by beneficiaries in acquiring the FIMAC I Loan at FIMAC Office.

The most significant challenges ranked in order of increasing importance include less transparent processes, difficult loan application processes and lack of collateral security. Other challenges as presented in Figure 5 include insufficient funds provided by FIMAC, untimely disbursement of funds, high interest rates and unclear time table for FIMAC activities.

Similarly, Figure 6 shows the challenges at the cooperative level ranked in descending order of importance, and highlights the mismanagement of funds (close to $60 \%$ ) and insufficient cooperative funds (close to $38 \%$ ) as the two key challenges faced by beneficiaries at the level of their respective cooperatives. However, poor storage facilities, lack of markets for produce and unclear time table of cooperative activities were other challenges faced by the beneficiaries within their respective cooperatives.

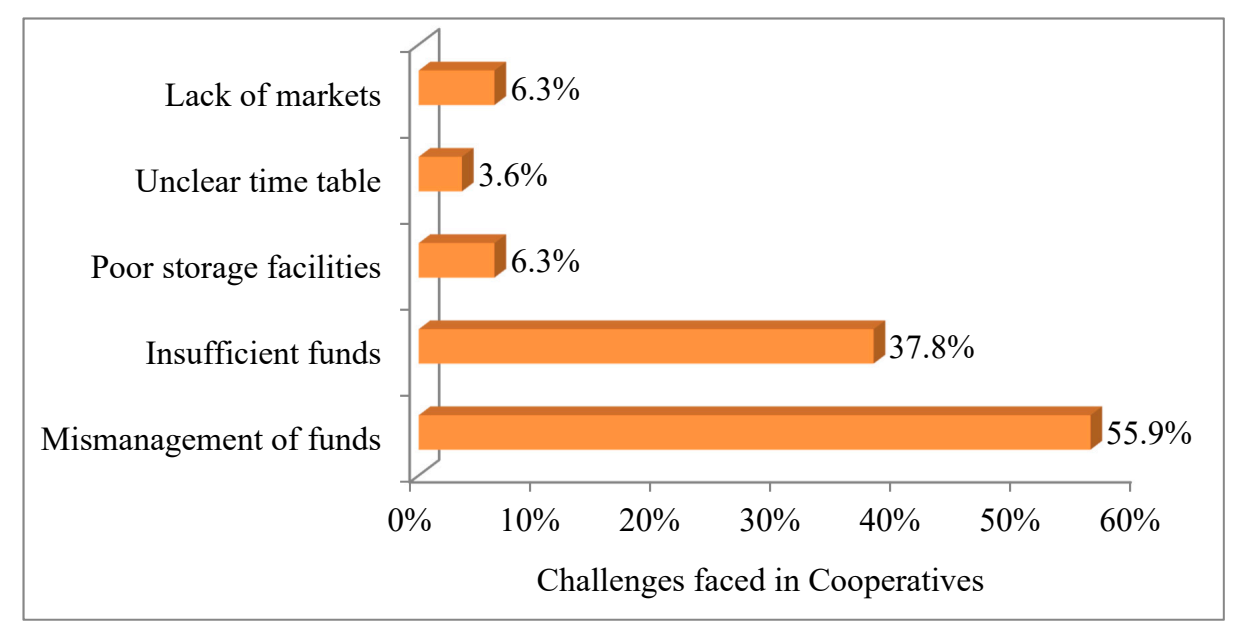

Figure 6. Challenges faced by beneficiaries in their cooperatives. 
The binary logistic regression test statistic (Table 8) was performed to reject or not the research hypothesis. The dependent variable (project continuity) took 1 for YES and 0 for NO. Nine (9) explanatory socio-economic variables were included in the analysis: age, number of adult children, number of dependent children, length of stay in the village, sex, main occupation, educational level, status (indigene or migrant) and the estimated seasonal income.

Table 8. Binary Logistic Regression Results.

\begin{tabular}{cccccc}
\hline Variable & B & S.E. & Wald & Sig. & Exp.(B) \\
\hline Age of beneficiary & -0.025 & 0.037 & 0.451 & 0.502 & 0.975 \\
Number of adult children & 0.044 & 0.095 & 0.217 & 0.641 & 1.045 \\
Number of dependent children & -0.046 & 0.105 & 0.192 & 0.661 & 0.955 \\
Length of stay in the village & 0.006 & 0.022 & 0.082 & 0.774 & 1.006 \\
Sex of beneficiary & 0.737 & 0.660 & 1.247 & 0.264 & 2.090 \\
Main occupation of beneficiary & -0.285 & 0.514 & 0.309 & 0.578 & 0.752 \\
Education level of beneficiary & 0.530 & 0.321 & 2.728 & 0.049 & 1.700 \\
Status (indigene or not) & 0.161 & 0.776 & 0.043 & 0.835 & 1.175 \\
Estimated income per season & 0.000 & 0.000 & 18.994 & 0.000 & 1.000 \\
Constant & -1.662 & 2.997 & 0.308 & 0.579 & 0.190 \\
\hline
\end{tabular}

The results show that the degree of project continuity by beneficiaries is determined by the number of adult children of the beneficiary $(B=0.044)$, length of stay in the village $(B=0.006)$, sex $(B=0.737)$, educational level $(B=0.53)$ and the status of the beneficiary (being an indigene or migrant $)(B=0.161)$, with significant contributions recorded with the educational level of the beneficiary $(B=0.53, p=0.049)$. On the other hand, project continuity was not determined by age of the beneficiary $(B=-0.025)$, the number of dependent children $(B=-0.046)$ and the main occupation of the beneficiary $(B=-0.285)$.

\section{Discussion}

The objective of this paper has been to analyze the challenges and prospects of sustaining donor-funded projects in the North West Region of Cameroon. Using a structured questionnaire and an interview guide, data was collected from randomly selected 150 beneficiaries of the FIMAC I loan scheme from two divisions in the North West Region of Cameroon. While our investigations revealed that some beneficiaries received just FCFA 16,000, others received as much as FCFA 4,500,000 for crop production, livestock rearing or for business investments. The amount received was found to be positively correlated with the age of the respondent, the estimated seasonal income, the main occupation of the respondent and the sector of investment. Therefore, having access to larger loans is a function of the age of the beneficiary, his/her seasonal income, being a male farmer as well as being involved in crop production. This result however, does not agree with previous findings which contend that microfinance loans are meant to specifically target the poor, especially women, who are more credit-constrained than men [63-65].

Analysis of the impacts of the FIMAC I loan scheme revealed an increase in the average quantity of crops produced (from 10.6 tons to 31.1 tons), an increase in livestock quantities (from 8 to 14), an increase in income (an average increase of $119.9 \%$ ) as well as an increase in savings (a $122 \%$ increase). These results support previous findings in Cameroon [43,46], and Kenya [66], which all observed a significant positive impact on crop yields and financial assets for the beneficiaries of agricultural development-oriented projects. As a secondary impact, there were investments made by the beneficiaries in other sectors, for instance their private businesses or the purchase of equipment, which they use in their individual skilled jobs. For instance, increases in yearly financial savings of USD352.8 and USD127.3 were registered respectively for Kenya [66] and Cameroon [43]. Our findings are also in line with that of [67] in the Asia-Pacific Region where they found out that the fisheries research project implemented in the region increased the production, productivity and disposable income of their beneficiaries. From the above results, it is clear that benefiting from the FIMAC I loan scheme has 
been accompanied by direct (increase in land owned, farm yields and livestock, increase in income) and indirect (extension of activities, increase in incomes from other sectors, savings) benefits enjoyed by the project beneficiaries. Although it is difficult to ascertain these claims without any established baseline data, the findings are consistent with a growing literature which links development projects and consumption to improvements in wellbeing of beneficiaries [67-70]. Another indirect benefit of development projects (though not yet an impact of this case study) is the change in government policies as a result of positive impacts of development projects. While this is still slow in Africa and Cameroon, there have been vast changes in the Asia-Pacific region in government policies as a result of development projects. The ACIAR-funded World Fish project in the Solomon Islands is a case in point. Because the project had a significant impact both on the way communities participated in decisions that affect their lives, and on the overall governance of natural resources in the Solomon Islands, the Ministry of Fisheries and Marine Resources (MFMR) has created a national strategy for inland fisheries and marine resources, recognizing both the importance of the fish project for food security and the importance of community involvement in co-managing these resources. In addition, communities who participated in the project have since created grassroots organizations and designed and implemented community-endorsed solutions that have fostered development in their respective communities [71-73].

In the process of implementing community projects in the North West Region of Cameroon (NWRC), the project-providers and the governmental agents have seldom incorporated the socio-cultural practices and institutions of the project beneficiary population. This is probably why mixed results were obtained with respect to the age of the beneficiary, the sex of the beneficiary, his/her status (indigene or a migrant), the total land owned, training received, number of adult children, main occupation, access and membership in groups, and other socio-economic variables, and their effect on project sustainability. One can thus conclude that project sustainability is largely affected by the socio-cultural nature of the beneficiary and his/her community. This is probably why several studies maintain that projects must incorporate the units of social life of the beneficiary population, as a first step towards sustainability [11,67,74-76]. In contrast with the arguments of Lord [77] we felt that including a complicated causal chain model may create unnecessary confusion. Thus, we opted to analyze and present the findings for each sustainability arm to encourage further discussion and interpretation by those who may use the results for future planning, investment and policy decisions [78]. Our findings revealed that the number of dependent children, the length of stay in the village, the educational level of the beneficiary and the sector of investment were robust across all three dimensions of sustainability and showed positive relationships in affecting the sustainability of the FIMAC-sponsored projects in the North West Region of Cameroon.

Of the entire variables affecting the sustainability of the FIMAC I loan scheme, the educational level of the beneficiary showed the strongest significant contribution to the sustainability of the FIMAC-sponsored projects. This significant contribution to project sustainability was strongest with respect to project continuity $(B=2.007, p<0.05)$, then project extension $(B=0.967, p<0.1)$. Its contribution to project adaptability was least in the rankings $(B=0.358, p>0.05)$. Therefore, as the educational level of the beneficiary increases by one year, their ability to adapt, continue and extend the FIMAC I project also increases. This is possible because as rural households and individuals acquire more education and experience especially in farming operations, accumulation of wealth and better planning, they tend to have better chances for sustaining their livelihood activities, which are translated into better management and sustainability of the FIMAC loan schemes. For example, similar results were found in the Lake Nyos area, in which the educational level of the 1986 Lake Nyos victims positively affected their choice of livelihood strategies [58]. Also, the educational status of beneficiaries was found to have a positive influence on the payment and sustainability of agricultural credit schemes in Nigeria [79], and in other similar contexts [76,80,81]. However, this result contradicts a case in South Africa, in which education was observed as a less important variable in predicting the repayment ability and sustainability of credits [82]. 
Based on our regression models, the sector of investment, whether crop production or livestock or business, was another variable with a positive contribution across the three dimensions of sustainability of the FIMAC I loan scheme. Though all the different sectors witnessed an upsurge in their financial assets, moving from crop production to business to livestock production, our results indicated that the sector of investment contributed strongly and significantly with respect to project extension $(\mathrm{B}=0.751, p<0.1)$. This result therefore suggests that while it is easier for beneficiaries involved in agriculture, and more specifically in crop production, to better adapt and continue their projects, it is even significantly easier for them to expand their project activities. Furthermore, similar findings were observed for Pakistan, where agricultural credits significantly contributed to improve the country's agricultural sector [83]. In the context of Europe and Asia, micro credit programs have equally significantly contributed to agricultural development [63-65,67].

The number of years the beneficiary had been living in the community was another variable that showed positive contributions across the three sustainability dimensions. This is probably true due to the fact that having stayed in the community for a very long time, beneficiaries may have accumulated more capital, for instance through income generation, land for agriculture, larger household sizes and high social affiliations in groups and Njangi which are good inputs for agriculture in the form of labor and capital. Thus, as these beneficiaries acquire more and more assets due to their long stay in the community, their abilities to adapt, continue, extend and sustain their respective FIMAC-sponsored projects also increases.

Respondents with a high family dependency level had more probability of default in the FIMAC loan repayment as well as sustainability. This variable tended to enhance credit risk among beneficiaries, especially in rural areas in developing countries. This high family dependency is usually associated with high domestic expenditures in maintaining large family sizes, and it is also confirmed by previous studies on this subject in Nigeria [79,84-86]. This was especially significant with respect to project adaptability ( $\mathrm{B}=0.550, p<0.1$ ). By not being able to adapt or sustain the projects, the livelihoods of such beneficiaries as well as those of their households can become insecure due to project failure and increased poverty. For example, in Ethiopia, similar results were observed, indicating that increases in dependent household members negatively affect the livelihood security of farming households [87]. In areas with relatively poor households and with a large share of the population concentrated in agriculture, increase in dependent household members limits the ability of the household to effectively manage their environment in order to attain sustainable development. This probably explains why the existence of poverty as a result of increased dependent children promotes environmental degradation, thus pushing project sustainability to its failure [33,35].

We can also deduce from our results that the accumulation of social capital, for instance high social affiliations in groups and Njangi, which are good inputs for agriculture in the form of labor, training and marketing, is important in project sustainability. For example, [88] also found out that social capital in the form of social groups and networks was significant in affecting loan acquisition and delinquency of agricultural loans in Kenya. Similar to the findings of this study, the findings of $[67,73]$ proved that communities who participated in the fish project in the Asian-Pacific Region also accumulated social capital through the creation of grassroots organizations that later designed and implemented community-endorsed solutions. Thus the accumulation of social capital irrespective of region (Africa or Asia) is a key component in the sustainability of development-funded projects.

For the challenges faced in the course of this project, the beneficiaries mentioned less transparent processes, difficult loan application processes and lack of collateral security as the three key challenges they faced in the course of this project. Also, high transaction costs and interest rates, difficult organizational operational prudency, and poor lending practices have been observed as limiting factors to agricultural loan schemes in Kenya [88]. Furthermore, studies on CAMCCUL in Cameroon identified collateral security to be a challenge for the poor to acquire agricultural loans [79,89]. As a remedy to these challenges, the beneficiaries suggested the following strategies to be implemented as a means to improve the performance of such development projects in the future: the creation of local self-finance 
groups that will carry out similar functions, the provision of training on key livelihood activities, the provision of equipment, the creation of a market information system, the timely disbursement of funds, putting in place of a transparent loan acquisition process, the creation of processing and storage centers, the reduction of loan interest rates and also improvement of the transportation facilities for farm produce.

\section{Conclusions}

This paper explored the determinants for the sustenance of FIMAC beneficiary projects in the North West Region of Cameroon, and the challenges and prospects of sustaining the FIMAC loan scheme in the region. While positive changes are registered through the FIMAC project interventions, for instance an average increase of $119.9 \%$ and $122 \%$ in seasonal incomes and savings, respectively, the sustainability question, defined in this context under adaptability, continuity and extension, remains highly contested. In the context of this study, several beneficiary socio-economic factors defined the sustainability of rural development projects. This was especially significant with respect to project continuity $(p<0.05)$. Policy contributions are therefore needed in the following areas: Firstly, government policies should continue to support such development projects as they have proven to have significant impacts on their target populations (for instance an average increase in 20.5 tons of crop productivity per year). Also, they should introduce soft loans with minimal demands for collateral security in order to increase beneficiary participation in the projects. Thirdly, FIMAC should further explore possibilities of scaling up loan scheme projects as one key strategy to achieve the state's objective of developing sustainable livelihoods, especially in rural populations. To increase project sustainability, it is recommended for such projects to be provided with tailor-made training especially for the "not-educated" farmers, before the provision of loans. The central conclusion of this paper is that sustainability outcomes remain highly nuanced in project interventions, taking the case of FIMAC loan scheme. Therefore, further studies should be conducted with other development projects to unbundle robust variables affecting project sustainability and the conditions under which donor-funded projects are rendered sustainable in rural communities. Furthermore, the policy environment which frames the application of FIMAC and similar loan schemes should be given due research attention.

Author Contributions: Conceptualization, design of research instruments, data collection, writing-original draft preparation, G.N.M.; analyzing data, writing — review and editing, N.K.A.; review of draft manuscript and supervision, J.N.K.

Funding: This research received no external funding. The APC was funded by the Technische Universität Dresden, Germany.

Acknowledgments: We deeply acknowledge the respondents who took out time to provide the relevant data by responding to the questionnaire. Many thanks to the research assistants who supported the data collection process. We equally thank the anonymous reviewers whose comments enriched the paper.

Conflicts of Interest: The authors declare no conflict of interest.

\section{Appendix A}

\section{Questionnaire}

This questionnaire has been developed to undertake research on "The Challenges and prospects for sustaining donor-funded projects: The Case of the FIMAC loan scheme in North West Cameroon", in partial fulfilment of the requirements for the award of an MBA in Project Management at the Catholic University of Cameroon (CATUC). The study is conducted strictly for an academic purpose and I, Muluh Gregory assure you of confidentiality in your responses. Please be kind to provide responses.

General Information

\begin{tabular}{|l|l|}
\hline Surveyor name & \\
\hline ID number of the respondent & \\
\hline Village/Neighbourhood & \\
\hline Date of interview & \\
\hline
\end{tabular}




\begin{tabular}{|l|l|}
\hline A. Demographic Characteristics of Respondents \\
\hline 1. $\quad$ Respondent & $\begin{array}{l}\text { Sex: } \square \text { Male } \square \text { Female } \\
\text { Position of respondent in the group: }\end{array}$ \\
\hline 2. $\quad$ Age of respondent & \\
\hline 3. Occupation $\square$ Farmer $\square$ business person $\square$ civil service $\square$ Others (Specify) \\
\hline 4. Give the estimated income per season \\
\hline $\begin{array}{l}\text { 5. Number of children; a. Dependent Children } \\
\text { b. Adult Children }\end{array}$ \\
\hline
\end{tabular}

6. Length of stay in the village or neighbourhood.

7. Highest level of education $\square$ illiterate $\square$ primary $\square$ secondary $\square$ vocational training $\square$ BSc

8. Are you an indigene or a migrant? $\square$ indigene $\square$ migrant

9. When did you join your group (year)?

B. Socio-Economic Considerations

10. What was your reason for joining the cooperative? $\square$ gain access to credit $\square$ benefit from farm inputs $\square$ benefit from training services $\square$ to benefit from market access $\square$ others (specify)

11. How often did you receive support from the FIMAC loan scheme? $\square$ monthly $\square$ quarterly $\square$ bi-annually $\square$ yearly

12. How much did you receive?

13. In which agricultural sector did you invest the loan? $\square$ Agriculture $\square$ livestock $\square$ others

14. When were you expected to pay the loan?

Did you respect the payment schedule? $\square$ Yes $\square$ No If No, Why?

15. Did FIMAC carry out trainings for Loan beneficiaries? $\square$ Yes $\square$ No

If yes, what was the type of training?

How regular were the trainings?

16. Have you participated in any training in the last 5 years? $\square$ yes $\square$ No

17. If yes, indicate the type of training

18. Who were the organizers of the training? $\square$ cooperative $\square$ FIMAC $\square$ others (specify)

19. Indicate the size of your farmland before the FIMAC scheme (number and area in ha/or acre)

$\square$ Total landholding__ _ Land for subsistence agriculture__ _ Land for commercial agriculture

$\square$ Land for livestock _ $\square$ Total land leased out _ $\square$ Total land leased in

$\square$ Other (specify) 
20. Indicate the size of your farmland today (area in ha/or acre)

$\square$ Total landholding__ _ Land for subsistence agriculture__ $\_$Land for commercial agriculture

$\square$ Land for nursery/tree plantations _ $\square$ Total land leased out $\square$ Total land leased in $\square$ Home garden__ $\square$ Pasture land__ $\square$ Other (specify)__

21. Has there been any change? $\square$ yes $\square$ no

22. Can you attribute the change to FIMAC support? $\square$ yes $\square$ no

23. If no, indicate the reason for the change

24. Indicate crop output before FIMAC support $\square$ Maize __ $\square$ Beans _ $\square$ Yams

$\square$ Cocoyam__ $\square$ Vegetables__ $\square$ Irish Potatoes__ $\square$ Other (specify)__

25. Indicate crop output after FIMAC support $\square$ Maize __ $\square$ Beans _ _ $\square$ Yams _

$\square$ Cocoyam__ $\_$Vegetables__ $\square$ Irish Potatoes__ $\square$ Other (specify)__

26. Are the changes due to support from FIMAC? $\square$ Yes $\square$ no

27. If no indicate the reason for the change

28. Indicate livestock products and Quantity before FIMAC support $\square$ Cattle _ _ $\square$ Sheep _ _ Goats__ $\square$ Chickens__ $\square$ Beehives__ _ Fish__ _ Other (specify)__

29. Indicate livestock products and Quantity after FIMAC support $\square$ Cattle _ _ $\square$ Sheep _ _ $\square$ Goats__ $\square$ Chickens__ _ Beehives__ Fish__ O Other (specify)__

30. Are the changes due to support from FIMAC? $\square$ Yes $\square$ no

31. If no indicate the reason for the change

C. Effect/Impact of FIMAC Loan Scheme

32. Apart from agriculture, indicate other income generating sources $\square$ private sector job $\square$ migration \& remittances $\square$ petit trading $\square$ arts and craft $\square$ civil service job $\square$ medicinal plant sales

33. Indicate the reasons for the choice of diversification strategies above

34. Which of the above is/are likely to generate more income?

35. Which other diversification strategies would you prefer?

36. Why? $\square$ easy access $\square$ high earnings $\square$ good markets $\square$ good knowledge about it

37. What is stopping you from doing it? $\square$ limited capital $\square$ no markets $\square$ poor knowledge about it $\square$ Others (specify)

\begin{tabular}{|l|l|l|l|}
\hline $\begin{array}{l}\text { 38. } \begin{array}{l}\text { Estimate your } \\
\text { income per season }\end{array} \\
\text { Agriculture }\end{array}$ & Before FIMAC Support & After FIMAC Support & 2018 \\
\hline Livestock & & & \\
\hline Other sectors & & & \\
\hline
\end{tabular}

39. Are you able to save? $\square$ yes $\square$ no

\begin{tabular}{|l|l|l|}
\hline 40. Monthly savings & Before FIMAC support & In 2018 \\
\hline & & \\
\hline
\end{tabular}

41. How likely are you to continue your project activities without FIMAC support? $\square$ very likely $\square$ likely 口undecided $\square$ less likely $\square$ unlikely 
42. How likely are you to self-finance your project? $\square$ very likely $\square$ likely $\square$ undecided $\square$ less likely $\square$ unlikely

43. How likely are you to acquire loan from other sources? avery likely alikely $\square$ undecided $\square$ less likely 口unlikely

Explain Your Choice of Answer

44. How likely are you to form a local credit scheme? $\square$ very likely $\square$ likely $\square$ undecided $\square$ less likely $\square$ unlikely

Explain Your Choice of Answer

45. Are you able to invest to extend your activities? $\square$ yes $\square$ no

46. Which credit institutions do you have an access to? $\square$ Savings groups $\square$ Relatives $\square$ Money lenders $\square$ Microcredit institutions $\square$ Market partners

47. What would you sell in case of emergency? $\square$ Livestock $\square$ Arts\&Crafts $\square$ Landed Property $\square$ Others (specify)

48. Which of the groups do you belong to? $\square$ Cooperatives $\square$ Associations $\square$ Community based organizations $\square$ Njangi houses $\square$ Other (specify)

49. What is the motivation to join the group?

50. What are your benefits from the groups? $\square$ Easy access to Loans $\square$ Trainings $\square$ Easy Marketing of Produce $\square$ Others (specify)

D. Challenges \& Prospects

51. Did you encounter challenges to acquire the FIMAC loan? $\square$ yes $\square$ no

52. Identify the challenges involved in acquiring the FIMAC loan $\square$ lack of collateral security $\square$ untimely disbursement of funds $\square$ high interest rates $\square$ insufficient funds $\square$ difficult loan application process $\square$ less-transparent process $\square$ unclear timetable $\square$ others (specify)

53. Identify the challenges involved in your cooperative $\square$ mismanagement of funds $\square$ insufficient funds $\square$ poor storage facilities $\square$ unclear timetable $\square$ lack of markets $\square$ others (specify)

54. Can the funds you obtained from FIMAC support your future initiatives? $\square$ yes $\square$ no

55. Have you been able to repay the loan? $\square$ yes $\square$ no

56. If no why?

57. Which training aspects are needed for farmers?

58. Which training aspects are needed for cooperative leaders?

59. What other challenges did you face in investing the FIMAC loan?

60. How can the FIMAC scheme be improved upon? $\square$ Training $\square$ provision of equipment $\square$ reduce interest rates $\square$ ensure timely disbursement of funds $\square$ create a market information system $\square$ create processing and storage centres $\square$ improve transport $\square$ create local self-financing groups $\square$ create transparent loan provision scheme $\square$ others (specify)

61. How can continuity (sustainability) of the scheme be ensured at the level of:

a) FIMAC office $\square$ provide training on resource mobilization and fund raising $\square$ create alliance with other financial institutions $\square$ ensure timely disbursement of funds $\square$ follow-up with loan recipients $\square$ liaise with private investors $\square$ others (specify)

b) Cooperatives $\square$ provide training on resource mobilization and fund raising $\square$ create alliance with other financial institutions $\square$ follow-up with loan recipients $\square$ others (specify)

c) Farmers $\square$ create self-help groups $\square$ build capacity on local fund raising schemes $\square$ others (specify) 
Thank you for filling in this questionnaire.

\section{References}

1. Bratton, M. Civil Society and Political Transition in Africa; Institute for Development Research: Boston, MA, USA, 1994.

2. Breitmeier, H.; Volker, R. Environmental NGOs in an Emerging Global Civil Society. In The Global Environment in the Twenty-First Century: Prospects for International Cooperation; Pamela, C., Ed.; United Nations University: Tokyo, Japan, 2000. Available online: http://www.ciaonet.org/book/chasek/ (accessed on 11 August 2018).

3. Gibson, C.C.; Andersson, K.P.; Ostrom, E.S. The Samaritan's Dilemma: The Political Economy of Development Aid; Oxford University Press: New York, NY, USA, 2005.

4. Sally, Z.; Gaskin, S.J.; Folifac, F.; Kometa, S.S. The effect of urbanization on community-managed water supply: Case study of Buea, Cameroon. Community Dev. J. 2013, 49, 524-540. [CrossRef]

5. Cooka, N.J.; Wright, G.D.; Andersson, K.P. Local Politics of Forest Governance: Why NGO Support Can Reduce Local Government Responsiveness. World Dev. 2017, 92, 203-214. [CrossRef]

6. Wood, T. Village Phone Replication Manual: Creating Sustainable Access to Affordable Telecommunications for the Rural Poor; The United Nations Information and Communication Technologies Task Force: New York, NY, USA, 2005.

7. Mujabi, S.; Otengei, S.O.; Kasekende, F.; Ntayi, J.M. Determinants of successful implementation of donor-funded projects in Uganda. Int. J. Soc. Econ. 2015, 42, 1139-1154. [CrossRef]

8. Azhar, N.; Farouqi, R.U.; Ahmed, S.M. Advancing and Integrating construction education, research \& practice, Cost Overrun Factors in the Construction Industry of Advancing \& Integrating Construction Education, Research and Practice. In Proceedings of the First International Conference on Construction in Developing Countries (ICCIDC-I), Karachi, Pakistan, 4-5 August 2008.

9. Collier, P.; Dollar, D. Aid allocation and poverty reduction. Eur. Econ. Rev. 2002, 46, 1475-1500. [CrossRef]

10. Komives, K.; Akanbang, B.; Thorsten, R.; Tuffuor, B.; Wakeman, W.; Larbi, E.; Whittington, D. Post-construction support and the sustainability of rural water projects in Ghana. In Proceedings of the 33rd WEDC International Conference, Accra, Ghana, 7-11 April 2008; pp. 1-294.

11. Clift, R. Climate change and energy policy: The importance of sustainability arguments. Energy 2007, 32, 262-268. [CrossRef]

12. Okenyi, J. An Overview of Sustainability in Project Management. 2013. Available online: https://www. researchgate.net/publication/309155554 (accessed on 15 November 2019).

13. Njoh, A.J. Citizen Participation and Sustainability: Lessons from Cameroon. Development 2011, 54, $376-383$. [CrossRef]

14. Rodney, W. How Europe Underdeveloped Africa; Bogle-L'Ouverture Publications: London, UK; Tanzanian Publishing House: Dar-Es-Salaam, Tanzania, 1973.

15. Ågerup, M.; Ayodele, T.; Cordeiro, J.; Cudjoe, F.; Fernandez, J.R.; Hidalgo, J.C. Successful adaptation to climate change across scales. Glob. Environ. Chang. Part A 2004, 15, 77-86.

16. Kimengsi, J.N.; Balgah, R.A.; Gwan, S.A. Enhancing Community Participation for Rural Development in Central Ejagham of Cameroon: Challenges and Prospects. Int. J. Community Dev. 2016, 4, 20-32. [CrossRef]

17. Labonne, J.; Chase, R.S. Do community-driven development projects enhance social capital? Evidence from the Philippines. J. Dev. Econ. 2011, 96, 348-358. [CrossRef]

18. Nkonya, E.; Phillip, D.; Mogues, T.; Pender, J.; Kato, E. Impacts of Community-driven Development Programs on Income and Asset Acquisition in Africa: The Case of Nigeria. World Dev. 2012, 40, 1824-1838. [CrossRef]

19. Himmelstrand, U.; Kinyanjui, P. African Perspectives: Controversies, Dilemmas, and Openings; Villiers Publication: London, UK, 1994.

20. Lyson, M.; Smut, C.; Stephens, A. Participation, Empowerment and Sustainability: How do the link work? Urban Stud. 2001, 38, 1233-1251.

21. Balgah, R.A. The Programme for the Improvement of Agro-Pastoral Family Farms and Poverty Reduction in Mezam Division, Cameroon. Univ. Buea J. Appl. Soc. Sci. 2018, 11, 1-24.

22. Kimengsi, J.N.; Balgah, R.A.; Buchenrieder, G.; Silberberger, M.; Hene, P.B. An empirical analysis of credit-financed agro-investments and income poverty dynamics of rural women in Cameroon. Community Dev. 2020, in press. 
23. Buchenrieder, G.; Gnilachi Nguefo, J.; Benjamin, E. Poverty alleviation through microcredit in Sub-Saharan Africa revisited: New evidence from a Cameroonian village bank, the Mutuelle Communautaire de Croissance. Agric. Financ. Rev. 2019, 79. [CrossRef]

24. Mayoux, L. The magic ingredient? microfinance \& women's empowerment A briefing paper prepared for the Micro Credit Summit, Washington, February 1997.

25. Asian Development Bank. Effects of Microfinance Operations on Poor Rural Households and the Status of Women; Operations Evaluation Department, Asian Development Bank: Mandaluyong, Philippines, 2007.

26. Dalgic, U.K. International Expert Organizations and Policy Adoption: The World Bank and Microfinance in the 1990s. Cult. Dyn. 2007, 19, 5-38. [CrossRef]

27. Aagaard, P. The global institutionalization of Microcredit. Regul. Gov. 2011, 5, 465-479. [CrossRef]

28. Scoons, I. Sustainability. Dev. Pract. 2007, 17, 589. [CrossRef]

29. Komalawati, D. Participatory and Project Sustainability: Participatory Integrated Development in Rain-Fed Areas (PIDRA) Project in East Java-Indonesia. Master's Thesis, Massey University, Palmerstone North, New Zealand, 2008; 96p.

30. Martha, C. The Sustainability of Donor Funded Projects in Malawi; MCSER-CEMAS-Sapienza University of Rome: Rome, Italy, 2013; 86p.

31. IFAD. Sustainability of Rural Development Projects, Best Practices and Lesson Learned by IFAD in Asia, North Eastern Region Community Resource Management Project for Upland Areas; TANGO International: Tucson, AZ, USA, 2009; 104p.

32. UNESCO. It's in the numbers-How sustainability will support Africa's long-term growth and development. In Proceedings of the WORLD ECONOMIC FORUM, Davos-Klosters, Switzerland, 20-23 January 2016. Available online: https://www.weforum.org/agenda/2019/09/why-sustainability-is-critical-for-the-long-termgrowth-and-development-of-africa/ (accessed on 15 November 2019).

33. Carbonnier, G.; Chakraborty, P.; Mulle, E.; Cartografare, I. Asian and African Development Trajectories Revisiting Facts and Figures. In Proceedings of the Framework of the Traverse Conference Organized by SDC, Bern, Switzerland, 16 June 2010.

34. Harrison, A.; Andres, R. From Hard to Soft Industrial Policies in Developing Countries. 27 June 2010. Available online: http://www.voxeu.org/index.php?q=node/5236 (accessed on 16 November 2010).

35. Mkandawire, T. The Terrible Toll of Post-Colonial Rebel Movements in Africa: Towards an Explanation of the Violence against the Peasantry. J. Mod. Afr. Stud. 2002, 40, 181-215. [CrossRef]

36. Amechi, E.P. Poverty, Socio-Political Factors and Degradation of the Environment in Sub-Saharan Africa: The Need for a Holistic Approach to the Protection of the Environment and Realization of the Right to Environment. Law Environ. Dev. J. 2009, 5, 107.

37. Okewu, E.; Misra, S.; Sanz, L.; Maskeliunas, R.; Dmasevicius, R. An e-Environment System for Socio-economic Sustainability and National Security. Probl. Sustain. Dev. 2018, 13, 121-132.

38. Spaling, H.; Brouwer, G.; Njoka, J. Factors affecting the sustainability of a community water supply project in Kenya. Dev. Pract. 2014, 24, 797-811. [CrossRef]

39. Spielman, D.J.; Zaidi, F.; Flaherty, F. Changing Donor priorities and strategies for agricultural R\&D in Developing Countries. Evidence from Africa. In Proceedings of the Forum for Agricultural Research in Africa, Accra, Ghana, 29 April 2011.

40. Thunde, D. Towards a transformation development organisation: Possible Challenges and Future. Lilongwe. Unpublished work. 1993.

41. Ademiluyi, I.A.; Odugbesan, J.A. Sustainability and impact of community water supply and sanitation programmes in Nigeria: An overview. Afr. J. Agric. Res. 2008, 3, 811-817.

42. Padawangi, R. Community-driven development as a driver of change: Water supply and sanitation projects in rural Punjab, Pakistan. Water Policy 2010, 12, 104-120. [CrossRef]

43. Balgah, R.A.; Mbue, I.N.; Ngwa, K.A. The impacts of renewable energy on livelihoods: A case study of biogas adoption in Cameroon. Int. J. Dev. Sustain. 2018, 7, 220-239.

44. Takwa, T.A.; Kimengsi, J.N. Investigating the role of agriculture, industry and foreign direct Investment in Cameroon's economic growth. Greener J. Soc. Sci. 2016, 6, 10-18.

45. Hene, P.B. The Role of ACEFA'S Microcredit Schemes in Poverty Reduction among Rural Women in Meme Division. Unpublished Thesis, Sustainable Development, Pan African Institute for Development West Africa, Buea, Cameroon, 2015. 
46. Tah, C.; Ngwa, K. Biogas Production: Impact on Farmers' Incomes. Int. J. Emerg. Trends Multidiscip. 2015, 1, 199-210.

47. Khan, G.N. The Effect of Capacity Building on the Sustainability of Water Supply Projects in Bafut of the North West Region. Unpublished Master's Thesis, Catholic University of Cameroon Bamenda, Bamenda, Cameroon, 2016.

48. Akei, M.L. Regional Institutions in Rural Council Area Development in the North West Region, Cameroon. J. Sustain. Dev. 2015, 8, 93-107. [CrossRef]

49. Futela, K.I. An Assessment of the Sustainability Strategies of GP-DERUDEP'S Local Development Fund Projects in Bamenda. Unpublished Master's Thesis, Catholic University of Cameroon Bamenda, Bamenda, Cameroon, 2015.

50. Kanayo, O.; Kizito, E.U.; Udefuna, P. The Challenges and Implications of Sustainable Development in Africa: Policy Options for Nigeria. J. Econ. Coop. Dev. 2013, 34, 77-112.

51. Takwa, A.C.; Kimengsi, J.N. An Empirical Analysis of PACA's Role in Rural Development in Mezam Division of Cameroon. Afr. J. Soc. Sci. 2016, 7, 3-12.

52. GP-DERUDEP. Rural Land Occupancy Plan (POER) for North West Region; Ministry of Agriculture and Rural Development (MINADER): Yaounde, Cameroon, 2003.

53. Batti, R.C. Development Project Management Within Local NGOs: 10 Recommendations to Meet 10 Challenges. Glob. Bus. Organ. Excell. 2015, 34, 21-29. [CrossRef]

54. FIMAC. Situation of First and Second Generation FIMAC Loans in the North West Province as of the 31st of March 2015; Fuchi Thomas Song, Ed.; FIMAC: Belo Horizonte, Minas Gerais, Brazil, 2005.

55. Gay, L.R.; Diehl, P.L. Research Methods for Business and Management; Macmillan: New York, NY, USA, 1992.

56. Khandler, R.S.; Koolwal, G.B.; Samad, H.A. Handbook on Impact Evaluation: Quantitative Methods and Practices; The World Bank: Washington, DC, USA, 2010.

57. Woodridge, J.M. Introductory Economics: A Modern Approach; McGraw-Hill: New York, NY, USA, 2009.

58. Ngwa, K.A.; Balgah, R.A. Determinants of Livelihood Security among Disaster Victims in Rural Cameroon. Int. J. Recent Sci. Res. 2016, 7, 8328-8334.

59. Jaza, F.A.; Tsafack, P.P.; Kamjou, F. Logit Model of Analyzing the Factors Affecting the Adoption of Goat Raising Activity by Farmers in the Non-pastoral Centre Region of Cameroon. TROPICULTURA 2018, 36, $54-62$.

60. Halloway, S. Achieving sustainability in customs capacity building. World Cust. J. 2008, 2, 63-70. Available online: www.worldcustsomsjournal.org (accessed on 15 October 2017).

61. Thompson, M. Sustainability is an essentially contested concept. SAPIENS 2011, 4, 1-4.

62. EXCHANGE-RATES.ORG. 2019. Available online: https://www.exchange-rates.org/Rate/USD/XAF (accessed on 29 September 2019).

63. Mieila, M. Measuring Sustainable Development and the Green Investments in Contemporary Economics. Valahia University of Targoviste: Târgoviște, Romania, 2018.

64. Rudd, A. Microfinance as a Poverty Alleviant: Have We Given It Too Much Credit? An Analysis of Variance in Welfare Outcomes. 2011. Available online: http://econweb.ucsd.edu/ \{\}rstarr/191Webpage/Exemplary\% 20Papers\%202011 (accessed on 6 September 2017).

65. Meyer, R.L. Innovative microfinance: Potential for serving rural markets sustainably. In Finance for Food: Towards New Agricultural and Rural Finance; Springer: Berlin/Heidelberg, Germany, 2014.

66. Hamlin, A. Assessment of Social and Economic Impacts of Biogas Digester in Rural Kenya; Independent Study Project (ISP) Collection: Brattleboro, VT, USA, 2012; p. 1247.

67. Hiruy, K.; Wallo, M. Impact Assessment: Assessing the social dimensions of fisheries research projects in the Asia-Pacific Region. Impact Assess. Proj. Apprais. 2018, 36, 444-455. [CrossRef]

68. Thilsted, S.H. The Potential of Nutrient-Rich Small Fish Species in Aquaculture to Improve Human Nutrition and Health. In Farming the Waters for People and Food, Proceedings of the Global Conference on Aquaculture 2010, Bangkok, Thailand, 22-25 September 2010; Subasinghe, R.P., Arthur, J.R., Bartley, D.M., Silva, S.S.D., Halwart, M., Hishamunda, N., Mohan, C.V., Sorgeloos, P., Eds.; FAO: Rome, Italy; NACA: Bangkok, Thailand, 2012; pp. 57-73.

69. Tacon, A.; Metian, M. Fish matters: Importance of Aquatic Foods in Human nutrition and global food supply. Rev. Fish Sci. 2013, 21, 22-38. [CrossRef] 
70. Béné, C.; Arthur, R.; Norbury, H.; Allison, E.; Beveridge, M.; Bush, S.; Campling, L.; Leschen, W.; Little, D.; Squires, D. Contribution of fisheries and aquaculture to food security and poverty reduction: Assessing the current evidence. World Dev. 2016, 79, 177-196.

71. Cohen, P.; Evans, L.; Govan, H. Community-Based, Comanagement for Governing Small-Scale Fisheries of the Pacific: A Solomon Islands' Case Study. In Interactive Governance for Small-Scale Fisheries; Jentoft, S., Chuenpagdee, R., Eds.; MARE Publication Series; Springer: Cham, Switzerland, 2015; Volume 13.

72. Orirana, G.; Siota, F.; Cohen, P.; Atitete, T.; Schwarz, A.; Govan, H. Spreading community-based resource management: Testing the "lite-touch" approach in Solomon Islands. In SPC Traditional Marine Resource Management and Knowledge Information Bulletin (37); SPC Fisheries: Noumea, New Caledonia, 2016; pp. 3-12.

73. Sukulu, M.; Orirana, G.; Oduagalo, D.; Waleilia, B.; Sulu, R.; Schwarz, A.; Van Der Ploeg, J.; Eriksson, H. Management over ownership: Modern community cooperation in Langalanga Lagoon, Solomon Islands. In SPC Traditional Marine Resource Management Knowledge Information Bulletin (37); SPC Fisheries: Noumea, New Caledonia, 2016; pp. 13-21.

74. Aksorn, P.; Charoenngam, C. Sustainability factors affecting local infrastructure project. Facilities 2015, 33, 119-143. [CrossRef]

75. Abbot, J.I.O.; Thomas, D.H.L.; Gardner, A.A.; Neba, S.E.; Khen, M.W. Understanding the links between conservation and development in the Bamenda Highlands, Cameroon. World Dev. 2001, 29, 1115-1136. [CrossRef]

76. Mah, V. Sustainability of Community-Managed Projects in the North West Region of Cameroon. Ph.D. Thesis, Cardiff Metropolitan University, Wales, UK, 2016.

77. Lord, F. Understanding social impacts by using new variables and a causal model diagram in New England fisheries. Impact Assess. Proj. Apprais. 2011, 29, 59-68. [CrossRef]

78. Esteves, A.; Franks, D.; Vanclay, F. Social impact assessment: The state of the art. Impact Assess. Proj. Apprais. 2012, 30, 34-42. [CrossRef]

79. Umoren, A.; Udoh, E.; Akpan, S. Analysis of loan default among agricultural credit guarantee scheme (ACGS) loan beneficiaries in Akwalbom State, Nigeria. Afr. J. Agric. Econ. Rural Dev. 2014, 2, 121-128.

80. Wilson, C.A.; Featherstone, A.M.; Kastens, T.L.; Jones, J.D. Determining What Really Important to Lenders: Factors Affecting the Agricultural Loan Decision-Making Process. 2015. Available online: http://ageconsearch. umn.edu/bitstream/28678/1/sp060007.pdf (accessed on 20 April 2015).

81. Featherstone, A.M.; Wilson, C.A.; Kastens, T.L.; Jones, J.D. Factors affecting the agricultural loan decision-making process. Agric. Financ. Rev. 2007, 67, 13-33. [CrossRef]

82. Johannes, I.; Henry, J. Determinants of Financial Sustainability for Farm Credit Applications-A Delphi Study. Sustainability 2016, 8, 77. [CrossRef]

83. Ahmad, N. Impact of Institutional Credit on Agricultural Output: A Case Study of Pakistan. Theor. Appl. Econ. 2011, 18, 99-120.

84. Eze, C.; Ibekwe, U. Determinants of Loan Repayment under the Indigenous Financial System in Southeast, Nigeria. J. Soc. Sci. 2007, 2, 116-120.

85. Ugbomeh, G.M.; Achoja, M.; Ideh, F.O.; Ofuoku, A.U. Determinants of loan repayment performance among women self-help groups in Bayelsa State, Nigeria. Agric. Conspec. Sci. 2008, 73, 189-195.

86. Udoh, E. Estimation of loan default among beneficiaries of a state Government owned agricultural loan scheme, Nigeria. J. Cent. Eur. Agric. 2008, 9, 343-352.

87. Bogale, A.; Shimelis, A. Household Level Determinants of Food Insecurity in Rural Areas of Dire Dawa, Eastern Ethiopia. Afr. J. Food Agric. Nutr. Dev. Rural Outreach Program 2009, 9, 1914-1926.

88. Echoka, J. Analysis of Determinants of Agricultural Credit Performance in Kenya: The Case of Agricultural Finance Corporation, Uasin Gishu District; University of Nairobi: Nairobi, Kenya, 2010.

89. Ngehnevu, C.; Nembo, F. The Impact of Microfinance Institutions (MFIs) in the Development of Small and Medium Size Businesses (SMEs) in Cameroon: A Case Study of CamCCUL; Department of Economics, Faculty of Natural Resources and Agricultural Sciences, Swedish University of Agricultural Sciences: Uppsala, Sweden, 2010.

(C) 2019 by the authors. Licensee MDPI, Basel, Switzerland. This article is an open access article distributed under the terms and conditions of the Creative Commons Attribution (CC BY) license (http://creativecommons.org/licenses/by/4.0/). 